\title{
Do Asian investors rebalance their portfolios and what are the consequences?
}

\author{
Alicia García-Herrero ${ }^{1}$ and Akiko Terada-Hagiwara ${ }^{23}$ \\ October 2006
}

\begin{abstract}
This paper explores empirically whether Asian investors, and in particular foreign reserve managers, respond to capital gains or losses by rebalancing their portfolios of US Treasury securities. For a sample of 10 Asian countries from 1990 to end 2004, we find that capital losses -stemming from dollar depreciation against the euro or lower returns on US Treasury securities -increase the net purchases of such securities. The fact that Asian investors appear to rebalance their portfolios should reduce the likelihood of one-directional movements in the net purchases of US securities. Given the sheer size of the US fiscal deficit, much of which financed by Asian investors, this should have contributed to limiting the volatility of the international monetary system.
\end{abstract}

Key words: portfolio rebalancing, reserve management, Asia

JEL classification: E44, E58, F31

\footnotetext{
${ }^{1}$ Alicia Garcia-Herrero is affiliated with the BIS Regional Office for Asia and the Pacific. She can be contacted at alicia.garcia-herrero@bis.org.

2 Akiko Terada-Hagiwara is affiliated with the Bank of Japan. She can be contacted at akiko.hagiwara@boj.or.jp.

${ }^{3}$ Views expressed in this paper are those of the authors and do not necessarily reflect the official views of the Bank of Japan or the BIS. Useful comments have been received from Claudio Borio, Andrew Filardo, Jacob Gyntelberg, Kentaro Kawasaki, Bob McCauley, Frank Packer, Eli Remolona, Daniel Santabarbara, Francisco Vazquez, Eliza Wu and participants to the International Conference on Financial System Reform and Monetary Policies in Asia, hosted by Hitotsubashi University (September 15-16, 2006). We also appreciate excellent research assistance by Eric Chan. Remaining errors are obviously the authors'.
} 


\section{Introduction}

This paper explores empirically what drives Asian investors' purchases of US government securities. In particular, it analyzes whether Asian investors - who are mainly official reserve managers - take into account capital gains or losses on their holdings of US securities when deciding on new purchases or sales. This question is important for Asian countries given the large and growing amount of foreign exchange reserves they hold, much of which held in US government securities. In addition, the sheer size of US securities issued and the large share held by Asian investors makes it a relevant issue for the international monetary system as a whole.

One can think of two opposite reactions to capital gains or losses on investment holdings. One possible reaction could be to buy more securities after having obtained capital gains and sell after incurring losses. Such kind of behavior - which could be defined as momentum trading - would lead to a relatively persistent pattern of net purchases of US government securities and, thereby, to the amplification of market movements with negative implications for volatility and, potentially, international financial stability as a whole. The other reaction would be for investors to purchase more securities after having incurred capital losses so as to maintain their desired portfolio. In the same vein, they should sell securities after obtaining capital gains to maintain their portfolio. Such behavior, known as portfolio rebalancing, should have a stabilizing effect on the net purchases of US government paper, as it would avoid sharp one-directional moves. The last possibility could be that investors do not react to capital gains or losses and that net purchases of US securities are explained by other factors, among which the search for yield.

In this paper, we test whether Asian investors rebalance their portfolio of US treasury securities. Since the bulk of investors are central banks, and US government securities are the most important instrument to accumulate US dollar reserves, this implies exploring how dollar reserves are managed. If portfolio rebalancing is confirmed, the share of dollar reserves should be relatively stable,, at least as US government securities are concerned.

For the specific case of foreign holdings of US government securities, capital gains and losses basically stem from exchange rate and interest rate movements, as long as they are 
not hedged. Assuming that no hedging takes place seems much more plausible for Asian investors, since most of them are official reserve managers.

Moving to a more detail explanation of the origin of capital gains and losses, let us consider the case of an appreciation of the US dollar. This would lead to an increase in the share of US dollar-denominated assets in investors' portfolio. Assuming that they had taken investment decisions in the previous period to achieve the optimal portfolio share in each currency, they would now be over-exposed to the US dollar, for a given level of investment. If the portfolio rebalancing hypothesis held, we should find that investors sell part of their US Treasury securities to reduce the US-dollar exposure. The opposite would be true in the case of dollar depreciation. As for interest rates, a higher return on US securities relative to the return on euro-denominated government securities of the same maturity would imply latent capital gains for investors, which would bring about an increase in the share of US-dollar denominated assets if investments were valued mark to market. Again, if portfolio rebalancing were behind investors' behavior, they would have to reduce their net purchases of US securities so as not to deviate from the optimal portfolio. The opposite would be true for a relative rise in the price of US securities.

In this paper, we show evidence that Asian investors do rebalance their portfolios of US Treasury securities although this is more the case as a reaction to capital losses than to capital gains. In addition, portfolio rebalancing is stronger before the Asian. More recently the search for yield seems to be determining the purchases of US securities by Asian investors.

The rest of the paper is structured as follows: Section 2 briefly goes over the literature and presents some stylized facts. Section 3 describes the data and the methodology. Section 4 shows the results obtained, and Section 5 concludes.

\section{Literature review and stylized facts}

To the best of our knowledge, the question of whether fixed income investors rebalance their portfolios - and more specifically reserve managers - have never been explored. The existing literature on portfolio rebalancing focuses on the stock market and the results are quite contradictory. Bohn and Tesar (1996) find little evidence of portfolio 
rebalancing by foreign investors in the US equity market. Hau and Rey (2004), instead, show that international equity returns, equity portfolio flows and exchange rate returns can be explained by portfolio rebalancing after controlling for endogeneity.

In the last few years, the rapid increase in foreign exchange reserves in many countries in the world has stepped up the interest in the composition of reserves and how they are managed. While some years ago reserves were thought to be "stored" rather than managed, there is growing evidence - such as a survey conducted by Central Banking Publications (Carver and Pringle, 2004)- that reserve managers are now more active. ${ }^{4}$ It is unclear, however, whether such activism includes the currency composition of reserves or is restrained to different instruments within the same currency of denomination. In fact, aggregate data on the currency composition of reserves shows a high and relatively stable share of US dollar reserves since the eighties, particularly for developing countries (Graph 1). ${ }^{5}$

\section{Graph 1: Share of US dollar-denominated reserves in international reserves}

As a percentage of international reserves

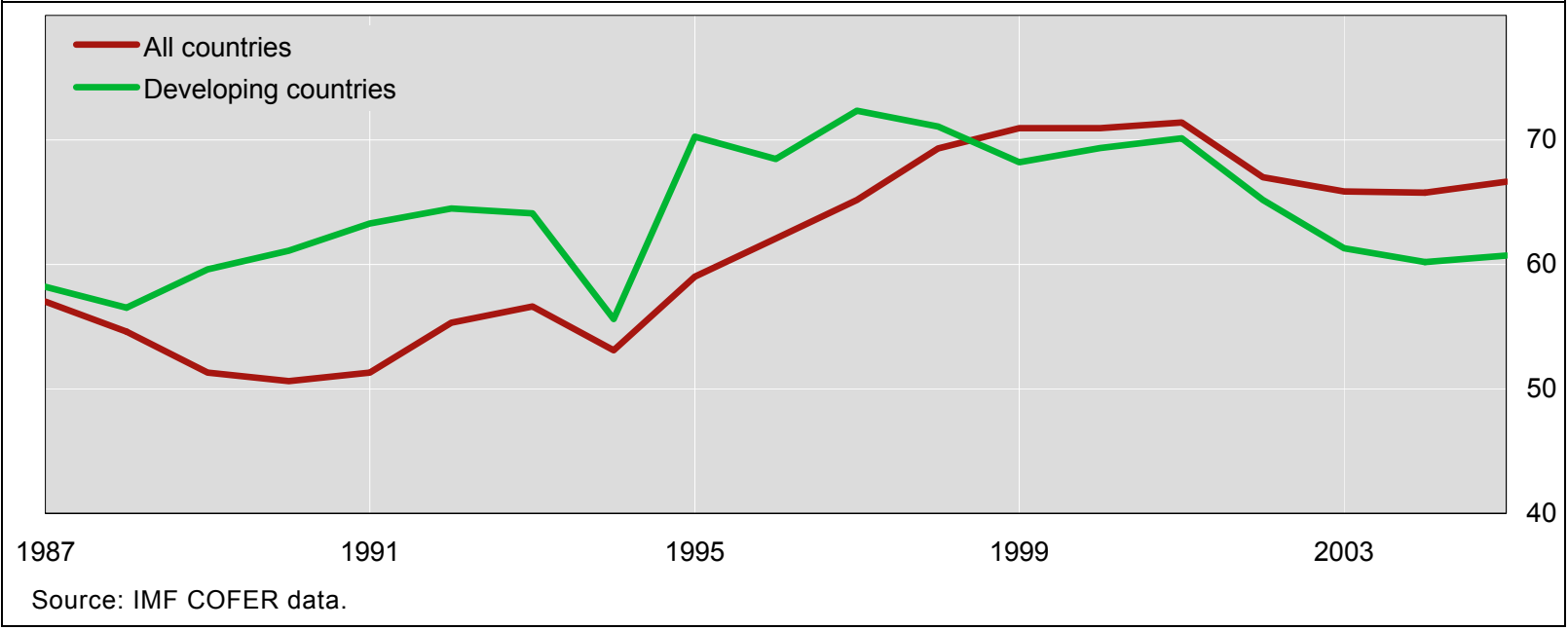

The high and relatively stable share of US dollar reserves-not withstanding the creation of the euro-has been the focus of empirical work by two different literature strands: the transaction cost approach and optimal portfolio theory. The former, led by Heller and Knight

\footnotetext{
${ }^{4}$ The guideline for the management of external assets (Bank of Japan, 2005) also shows an example of how portfolio rebalancing may be taking place, though this guideline applies to only about $5 \%$ of total international reserves held by the Bank of Japan as end of March 2006.

${ }^{5}$ This data should be taken with care since it suffers very large revisions from year to year, particularly in the eighties.
} 
(1978) and followed by Dooley, Lizondo, and Mathieson (1989), provides evidence in support of the view that transaction needs-stemming from trade links and the exchange rate regime-play a major role in determining the currency composition of reserves. However, the continuously decreasing trade share with the US -while increasing with Asian countries (Graph 2) - and the flexibilization of Asian exchange rates against the US dollar (Graph 3) would seem to weaken the transactions rationale for the accumulation of US dollar-denominated reserves.

\section{Graph 2: Trade share with the US and Asian countries}

As a percentage of total trade

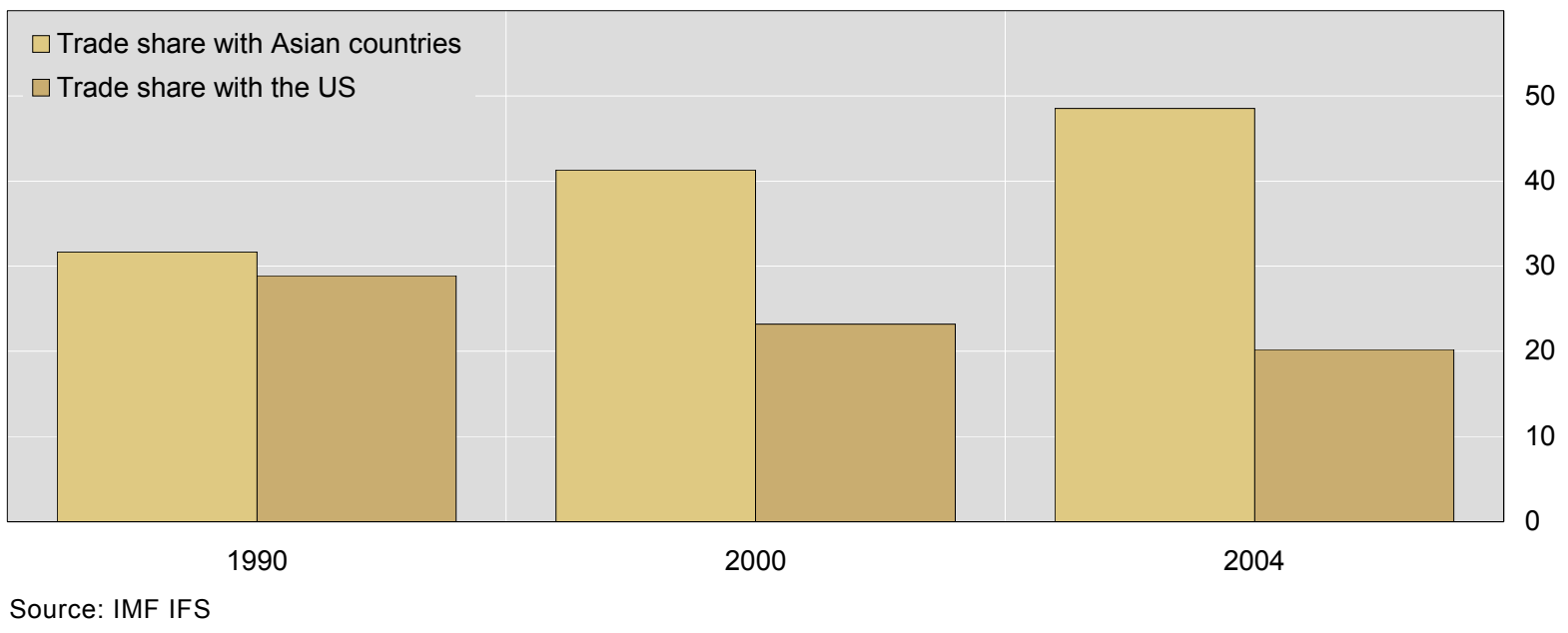

\section{Graph 3: Exchange rate classification (in relation to the US dollar)}

Categorical: 2 (pre-announced peg or currency board arrangement) - 14 (freely floating and hyperfloat)
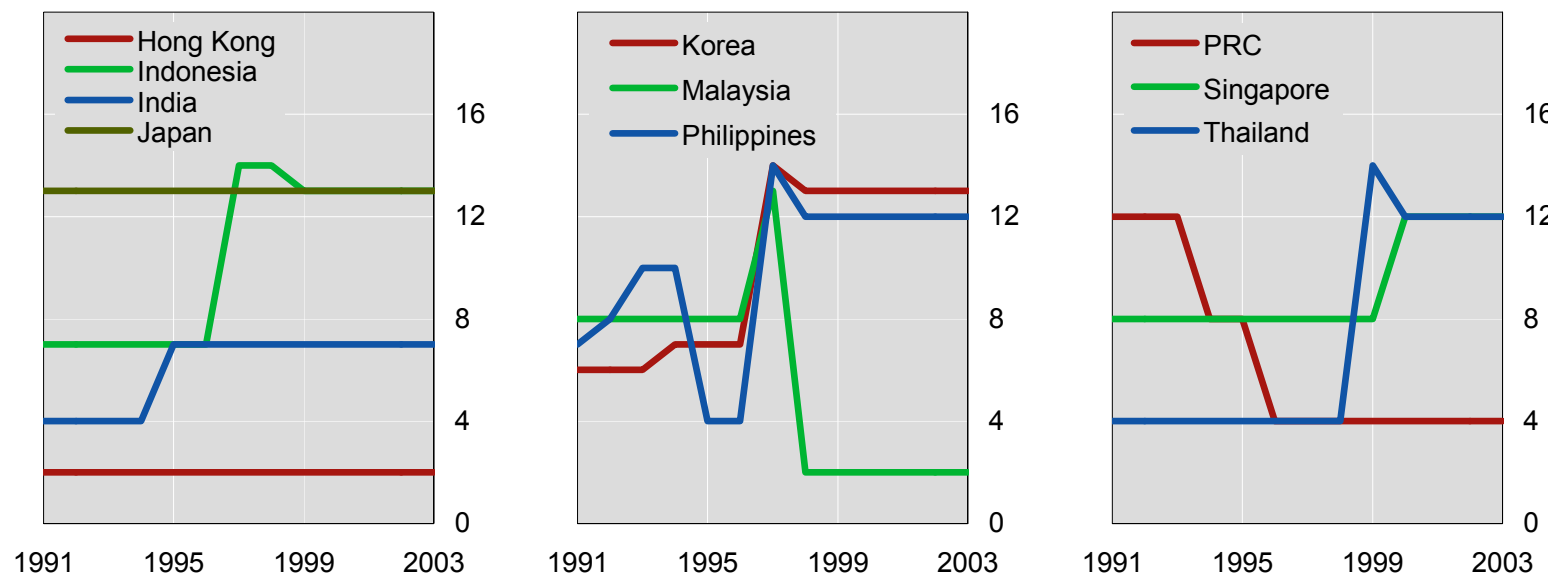

Source: Reinhart and rogoff (2004) 
The optimal portfolio approach, instead, argues that reserve managers do try to maximize returns for a given level of risk (Ben-Bassat, 1980). ${ }^{6}$ While the risk-adjusted expected return is very hard to determine, we can compare the ex-post returns of a US Treasury debt securities with that of a euro-denominated securities of the same maturity. If we take a three year maturity as the average for US government securities (the one used in our empirical study) and a German bond of the same maturity, as best representative of euro-denominated securities, neither of the two securities is clearly superior: we find periods in which the US-denominated one outperforms the euro security and other in which the euro-denominated one does (Graph 4$)^{7}$

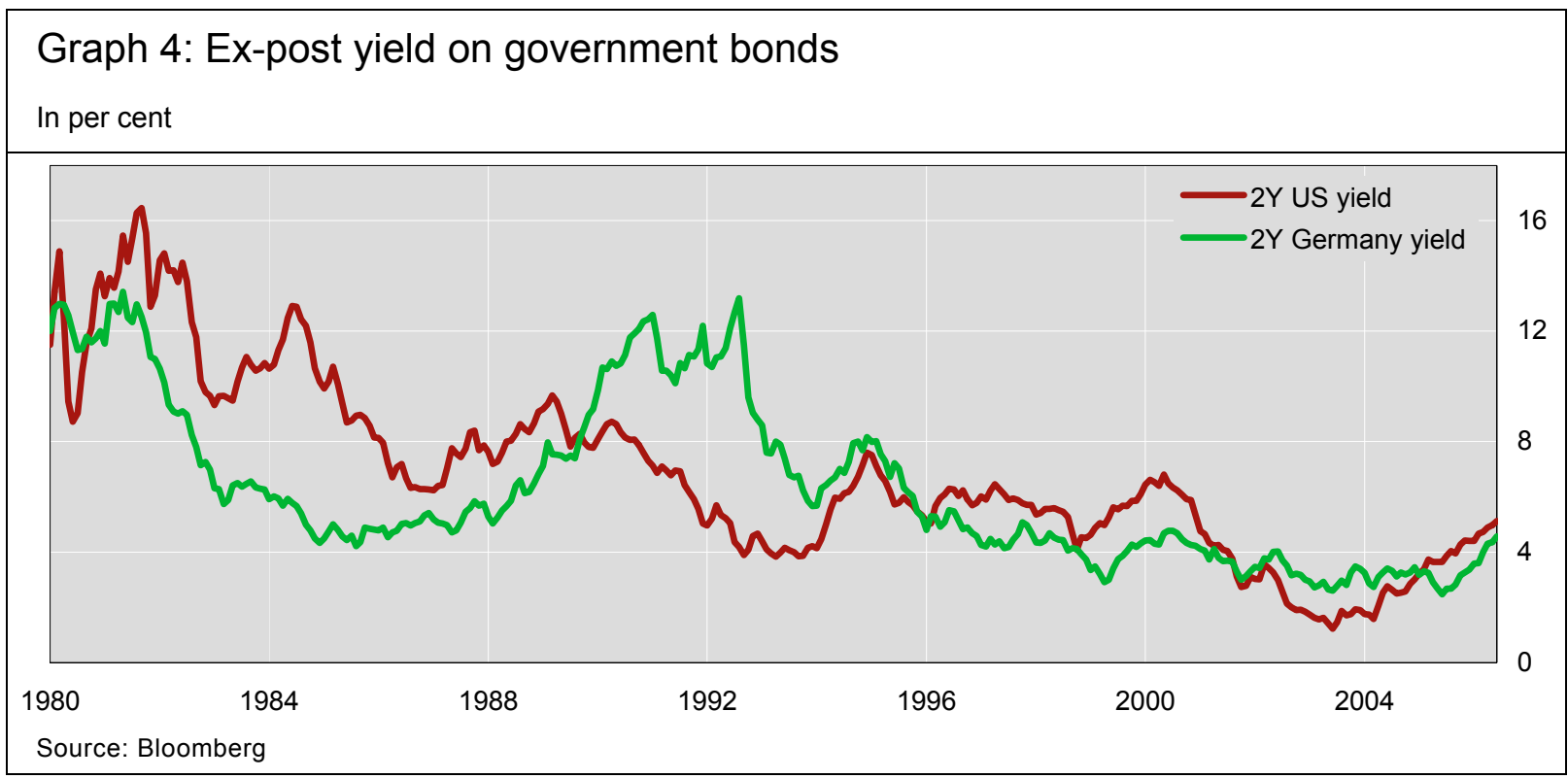

\section{Data used and methodology}

To test whether Asian investors - and in particular reserve managers -rebalance their portfolios, we analyze net purchases of US government debt securities by Asian countries. One could wonder why we do not directly use international reserves data to explore this question. The reason is that very few central banks unveil the currency and instrument break-down of their foreign exchange reserves-needed to estimate valuation

\footnotetext{
${ }_{7}^{6}$ Other recent attempts are such as Claessens and Kreuser (2004) and Fisher and Lie (2004).

${ }^{7}$ It should be noted that the German bond was denominated in Deutsche Mark before the creation of the euro on January 1, 1999.
} 
effects from market changes-and only one is Asian (namely the Philippines and only recently).

We, therefore, use net purchases of US government securities by Asian investors. While this kind of data could at first look quite unrelated to the question we want to answer, there are three reasons why this is not the case. The first one is that foreign official institutions are important purchasers of US Treasury securities: about $65 \%$ of total purchases for the world as a whole (Graph 6) and even higher for Asian according to anecdotal evidence. ${ }^{8}$ This is not the case for US agency securities, and even less so for corporate bonds and equities so that we would not be able to analyze the behavior of reserve managers with that kind of data. $^{9}$

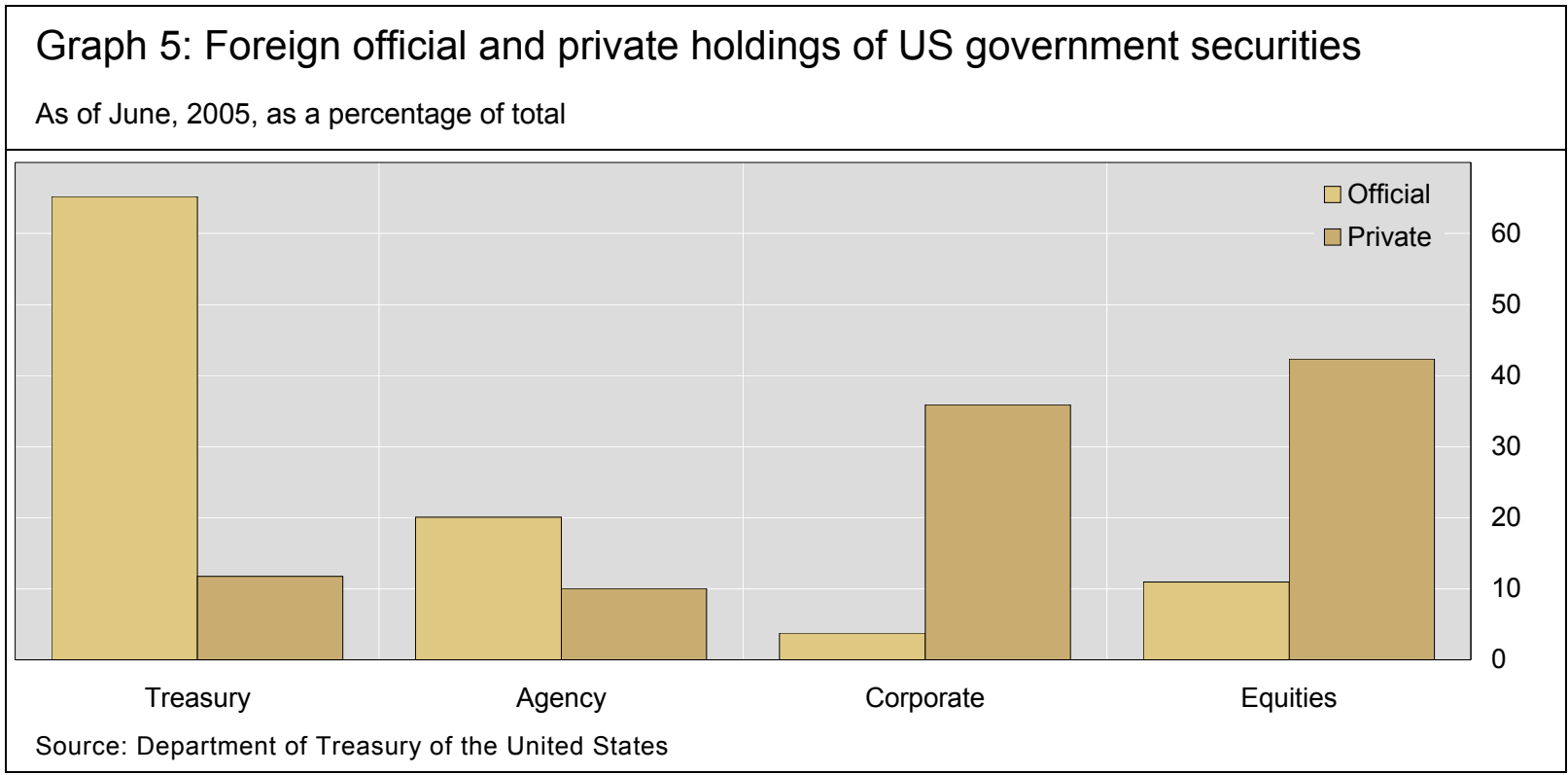

The second reason is that US government paper is the main instrument used by central banks to accumulate reserves and, in particular, dollar reserves. ${ }^{10}$ As much as $58 \%$ of dollar reserves were held in US government securities in 2000 while it is now about $41 \%$

\footnotetext{
${ }^{8}$ It should be acknowledged, though, that Asian official authorities can use intermediaries for their net purchases of US treasury securities, which would not appear in the data we use.

${ }^{9}$ Analyzing the behavior of Asian investors as a whole would also not be feasible. This is because the determinants of the purchases would be different for official and private investors and also because the latter might hedge their positions.

${ }^{10}$ Wooldridge (2006) provide a good overview of sources available to explore the composition of international reserves.
} 
(Graph 5). ${ }^{11}$ The third reason is that we need to focus on one instrument and one currency to analyze whether reserve managers rebalance their portfolio as a consequence of capital gains or losses: we simply choose the most relevant one.

\section{Graph 6: Composition of US dollar international reserves worldwide}

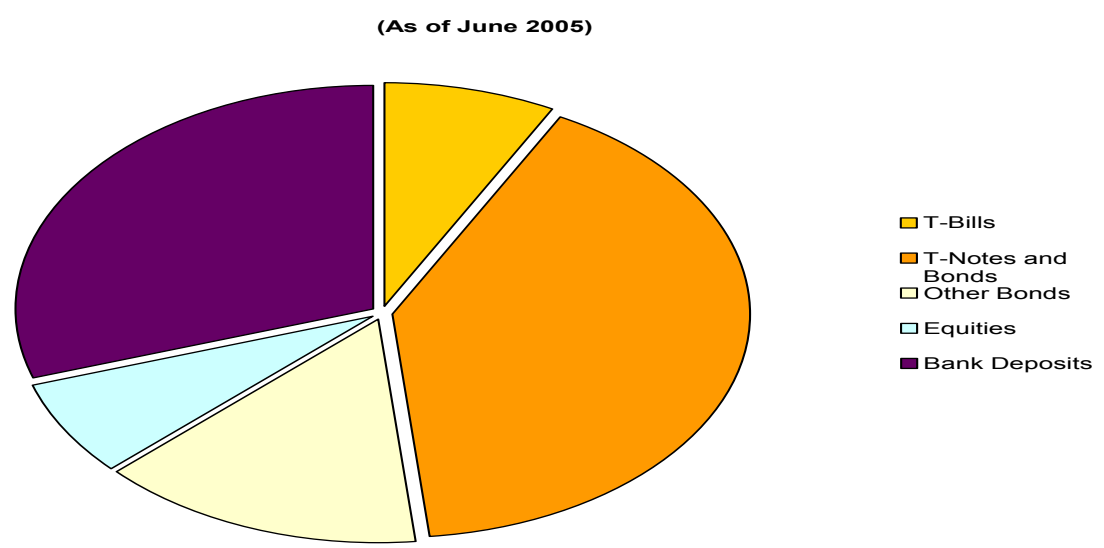

Source: Department of US Treasury; US Bureau of Economic Analysis; Japan Ministry of Finance; BIS; authors' own calculations.

The share of US government debt securities held by foreigners has more than tripled since the US Treasury launched the first survey on the holdings of the US security market in 1974 , known as the Treasury International Capital reporting system (TIC). Furthermore, Asian holdings are the largest, with $42 \%$ of total foreign holdings of long term debt securities, according to the most recent survey of 2005. Within Asia, Japan and the People's Republic of China (PRC) hold the largest share, $56 \%$ and $17 \%$, respectively. ${ }^{12}$ Other 8 Asian countries analyzed in this paper are Hong Kong, Indonesia, India, Korea, Malaysia, Philippines, Singapore, and Thailand. ${ }^{13}$

\footnotetext{
${ }^{11}$ The second most widely used instrument, bank deposits (with more than one third of total US dollar reserves) but it cannot be used to test whether portfolio rebalancing takes place. This is because it does not allow identifying the country making the deposit.

${ }^{12}$ Since the foreign owner of a US security may entrust the management or safekeeping of a security to a custodian, these figures are probably underestimating the share of US government securities purchased and held by Asian countries. In fact, among the ten countries with the largest holdings of US securities, there are several off-shore financial centers, such as the Cayman Islands or Switzerland.

${ }^{13}$ The survey reports data for Sri Lanka, Pakistan, and Taiwan as well. We do not include them in our sample due to their small transaction volumes for Sri Lanka and Pakistan, and to the missing exchange classification index for Taiwan, which is one of our control variables.
} 
The TIC survey offers a breakdown of monthly net purchases of US government debt securities into less than one year (T-bills) and more than one year (T-notes and bonds), and reports that the maturity structure of this latter group concentrates between 1-5 years making up more than $50 \%$ of total. On the private versus official nature of the foreign holders of US government securities, only aggregate information exists but not country by country. However, as has already been mentioned, it can safely be argued that a very large share of the Asian holdings of US long-term government securities is in official hands. This is even more so the case since capital controls on outflows, though varying in degrees, have been in place in most of our sample countries except for financially developed countries, such as Hong Kong, Japan, and Singapore.

In order to explore whether portfolio rebalancing affects Asian's net purchases of US long-term government debt securities, we follow Bohn and Tesar (1996)'s set out. They show that net purchases of a certain asset can be decomposed in two determining factors; one that arises from a change in the desired portfolio and the other that stems from capital gains or losses on the total portfolio and on the US Treasury securities as follows. ${ }^{14}$

$$
N P_{i, t}=\left(x_{i, t}-x_{i, t-1}\right) W_{i, t-1}+\left(c_{i, t}-c_{i, t}^{u s}\right)\left(x_{i, t-1} W_{i, t-1}\right)
$$

where $N P_{i t}$ be the net purchases of US government securities by an Asian country i at time t. $x_{i t}$ stands for the portfolio share of total wealth $\left(W_{i, t-1}\right)$ allocated to US government securities. $W_{i t}$ is proxied with the stock of exchange rate reserves, as most of the investors are official institutions. $c_{i, t}$ and $c_{i, t}^{u s}$ stand for capital gains on the total portfolio and capital gains on the US dollar denominated securities, respectively, both expressed in US dollar terms.

In order to calculate capital gains and losses on the US government securities held by Asian countries, we need to think of the available choice for an average reserve manager at an Asian official institution. For simplicity, we assume that he can only choose between US

\footnotetext{
14 This setout is approximated from the fact that $N P_{i t}$ can be written as $N P_{i, t}=x_{i, t} W_{i, t}-\left(1+c_{i t}^{u s}\right)\left(x_{i, t-1} W_{i, t-1}\right)$, and $W_{i t}$ is a function of the return on the total portfolio between t-1 and t (Bohn and Tesar (1996)).
} 
dollar or euro assets. This means that capital gains or losses can stem from changes in the dollar euro exchange rate, as well as price changes in US government securities relative to those in euro-denominated securities of the same maturity, liquidity and credit risk. The capital gains on the total portfolio $c_{i, t}$ can, then, be written as follows.

$c_{i, t}=\left(1-x_{i, t}\right) c_{i, t}^{e}+x_{i, t} c_{i, t}^{u s}$

By replacing $c_{i, t}$ in equation (1) with equation (2), $N P_{i t}$ can be written as follows:

$N P_{i, t}=\left(x_{i, t}-x_{i, t-1}\right) W_{i, t-1}+\left(c_{i, t}^{u s}-c_{i, t}^{e}\right)\left(1-x_{i, t-1}\right)\left(x_{i, t-1} W_{i, t-1}\right)$

where $\left(c_{i, t}^{u s}-c_{i, t}^{e}\right)$ stands for the relative capital gains on that portfolio as compared to one of a similar maturity, risk and liquidity but denominated in euros.

Given the fact that the holdings of long-term US government securities are very concentrated on the 1-5 year maturity, we assume that their average remaining maturity to be 3 years. ${ }^{15}$ We, thus, take the price of a three-year US government bond and that of a three year German bond to calculate interest-rate related capital gains or losses. ${ }^{16}$ We can quite safely assume that liquidity and credit risk are the same. Capital gains on US securities relative to those on euro will, then, be defined in the following way:

$c_{i t}^{u s}-c_{i t}^{e u}=\ln \left(e_{t} / e_{t-1}\right)+\left\{\left(r_{t}^{\$}-r_{t-1}^{\$}\right)-\left(r_{t}^{e}-r_{t-1}^{e}\right)\right\}$

where $e_{t}$ stands for euro exchange rate vis-à-vis US dollar (i.e., an increase in $e_{t}$ implies a dollar appreciation), $r_{t}^{\$}$ and $r_{t}^{e}$ stand for returns on the US government securities and on German government securities of a three-year maturity.

As for the first term of equation (3), the question is how the share of securities, $x_{i t}$, is chosen. We test the two major explanations offered by the literature: the transaction costs and the portfolio optimization. The former implies that trade with the US, borrowing in US dollar or an exchange rate regime linked to the dollar should increase the demand for US dollar reserves and, thereby, for US government securities. Since we are trying to explain a flow variable (net purchases of US paper and not the outstanding stock), we test whether changes in transaction costs affect the currency breakdown of reserves by increasing or

\footnotetext{
${ }^{15}$ Robustness tests are conducted with other maturities, such as two and five years. Three years is preferred because the two-year period could be more influenced by monetary policy expectations and the five year period is too long an average maturity for our sample. ${ }^{16} \mathrm{~A}$ German bond was chosen since it is more similar to a US treasury in terms of liquidity and risk.
} 
decreasing such net purchases. Two variables stand for the transaction costs: Trade ${ }_{i, t}$ and $E_{x c h}$. The former is proxied by the sum of imports and exports to the US as percentage of each Asian country's total imports and exports. The latter measures the degree of flexibility of the exchange rate regime using the de-facto exchange rate classification constructed by Reinhart and Rogoff (2004). This is a categorical variable, which goes from 2 to 14; the higher number indicates a more flexible exchange rate. A priori is that the fixer the regime against the dollar, the larger the need for US dollar denominated reserves for intervention purposes. The amount of debt in US dollar could not be included due to the low frequency of the data (annual, if available).

As for the hypothesis that reserves are managed according to optimal portfolio theory, we assume that the degree of risk aversion is fixed, and the variance-covariance matrix of returns is constant. These assumptions allow us to focus on a change in returns as a factor affecting the portfolio weight adjustment. To that end, we include an additional term in the equation measuring the expected risk-adjusted rate of return of US government securities relative to euro-denominated ones. We measure the risk-adjusted return with the Sharpe ratio (average yield divided by the standard deviation, Sharpe ${ }_{t}=r_{t}^{u s} / s d\left(r_{t}^{u s}\right)-r_{t}^{e} / s d\left(r_{t}^{e}\right)$ ) and assume today's value to be the best forecast of tomorrow's risk-adjusted return (i.e., a random walk). Since we assume that investors choose their preferred portfolio based on the transaction costs and the risk-adjusted profitability of the previous period, the preferred share of US treasury securities, $x_{i t}$, is a linear function of the three variables as follows.

$x_{i t}=f\left(\right.$ Trade $_{i, t-1}$, Exch $_{i, t-1}$, Sharpe $\left._{t-1}\right)$

That preferred portfolio is, then, affected by exchange rate and interest rate developments, which lead to capital gains or losses. Such capital gains and losses stemming from the previous period may affect investors' net purchases of US government securities today. The process is then repeated and investors recalculate their preferred portfolio on the basis of changes in transaction costs and risk-adjusted profitability. In other words, the determinants of the optimal portfolio entered the equation explaining net purchases of US 
securities with one lag while the portfolio rebalancing hypothesis enters contemporaneously. ${ }^{17}$

We replace the first term of equation (3) with equation (5), and divide by investors' total wealth in the previous period, $W_{i, t-1}{ }^{18}$, we obtain the following estimating equation:

$$
\frac{N P_{i t}}{W_{i, t-1}}=\beta_{1}\left(c_{i t}^{u s}-c_{i t}^{e u}\right)\left(1-x_{i, t-1}\right) x_{i, t-1}+\beta_{2} \text { Trade }_{i, t-1}+\beta_{3} \text { Exch }_{i, t-1}+\beta_{4} \text { Sharpe }_{t-1}+\varepsilon_{i t}
$$

where $c_{i t}^{u s}-c_{i t}^{e u}$ stands for the relative capital gain as defined in equation (4); Trade $_{\mathrm{i}, \mathrm{t}-1}$ refers to a change in trade share with US in the previous period; $\mathrm{TR}_{\mathrm{i}, \mathrm{t}-1}-\mathrm{TR}_{\mathrm{i}, \mathrm{t}-2}, \mathrm{Exch}_{\mathrm{i}, \mathrm{t}-1}$ stands for a change in the de facto exchange rate regime in the previous period, $E_{i, t-1}-E_{i, t-2}$; and Sharpe $t_{t-1}$ represents the change in the risk-adjusted return on of a two-year US government security as compared to a German one of the same maturity. ${ }^{19}$ $\varepsilon_{i t}$ is the error term.

Equation (6) shows the two previously mentioned components to an investors' decision to purchase US government securities. The first term is the portfolio rebalancing effect given the preferred share determined in the previous period, $x_{i t-1}$. If capital gains on the share of US government securities are larger than that on euro-denominated assets, i.e., if $\left(c_{i, t}^{u s}-c_{i, t}^{e}\right)$ are positive, the investor should sell off some of his/her outstanding US government securities to approach his/her desired portfolio. The opposite would be true if the relative capital gains $\left(c_{i, t}^{u s}-c_{i, t}^{e}\right)$ are negative. The second component indicates that net purchases will be positive if the investor's desired weight of that specific currency/instrument increases between period $\mathrm{t}-1$ and $\mathrm{t}$.

\footnotetext{
${ }^{17}$ In theory, this should be a continuous-time problem but it can be safely assumed that investors -and in particular reserve managers - take decisions with a certain frequency. ${ }^{18}$ The fact that we divide by $W_{i, t-1}$ also implies that we are controlling for trends in the total amount of reserves. In other words, the accumulation of reserves is treated as exogenous and controlled for. This is because the paper aims at understanding investment decisions across instruments and currencies and not at explaining the level of reserves. In addition, taking wealth one period before allows our dependent variable not to be influenced by the evolution of exchange and interest rates between $\mathrm{t}-1$ and $\mathrm{t}$.

${ }^{19}$ Further details can be found in Table A1 in the Appendix.
} 
Finally, separating the relative capital gains in the exchange rate and the return component as in (4), we would have the following estimation equation:

$$
\begin{gathered}
\frac{N P_{i t}}{W_{i, t-1}}=\gamma_{1} \ln \left(\mathrm{e}_{\mathrm{t}} / \mathrm{e}_{\mathrm{t}-1}\right) x_{i, t-1}\left(1-x_{i, t-1}\right)+\gamma_{2}\left\{\left(r_{t}^{u s}-r_{t-1}^{u s}\right)+\left(r_{t}^{e}-r_{t-1}^{e}\right)\right\} x_{i, t-1}\left(1-x_{i, t-1}\right) \\
+\gamma_{3} \text { Trade }_{i, t-1}+\gamma_{4} \text { Exch }_{i, t-1}+\gamma_{5} \text { Sharpe }_{t-1}+\eta_{i t}
\end{gathered}
$$

We have monthly panel data for 10 countries for the period 1990 to 2004 . This amounts to 1514 observations. The monthly frequency tries to strike a balance between the transaction cost-related reasons to accumulate reserves and the others (portfolio rebalancing and search for yield). The latter are probably a high frequency event as compared with the share of trade or the flexibility of the exchange rate regime, which do not change so often. ${ }^{20}$ The sample starts in 1990 as Asian investors were hardly active in that market before 1990 . A statistical summary of all the variables included in our regressions can be found in the Appendix (Table A2).

Regarding the methodology, we face several challenges to estimate in the most accurate way whether portfolio rebalancing affects the net purchases of US government securities. The first one is endogeneity, since it could bias our estimated coefficients. Endogeneity could be due to reversed causality since some argue that the purchase of US government securities by Asian investors could be large enough to affect Euro-US dollar exchange rate or interest rate developments. ${ }^{21}$ Endogeneity could also stem from simultaneity in the determination of exchange rate and interest rate movements. Another potential problem is unobserved heterogeneity, since we have 10 different countries in our sample. In order to tackle both potential endogeneity and unobserved hetoregeneity problems, we estimate our panel with the Generalized Method of Moments (GMM), following Arellano and Bond (1991).

\footnotetext{
${ }^{20}$ Choosing a monthly frequency has the disadvantage that a potentially important transaction cost determinant cannot be included in the sample, namely short-term debt.

${ }^{21}$ We conduct Granger-causality tests to examine this hypothesis and do find reverse causality (net purchases of US treasury securities Grange-causing capital gains) in the case of India, Korea, Malaysia, Philippines, PRC and Singapore (see Table A3 in Appendix).
} 
The Arellano-Bond estimator - also called system GMM estimator - combines the regression expressed in first differences (lagged values of the variables in levels are used as an instrument) with the original equation expressed in levels (this equation is instrumented with lagged differences of the variables) and allows to include some additional instruments. $^{22}$

We prefer this option to a fixed-effects estimator for several reasons. First, it allows us to take into account unobserved time-invariant country-specific effects. Second, the potential persistence of the dependent variable is accounted for by including the lag as an additional regressor. ${ }^{23}$ Finally, endogeneity is tackled by instrumenting with the lagged differences of the dependent and objective variable (the capital gains) ${ }^{24}$ considering all possible instruments yields the most efficient -as well as unbiased -estimators.

\section{Results}

As a first exercise we estimate whether Asian investors react to capital gains and losses on their portfolio of US government securities, when other controls are taken care of, namely the trade share with the US, the flexibility of the exchange rate regime ${ }^{25}$, and the risk adjusted rate of return.

In order for portfolio rebalancing to occur, Asian investors should reduce their net purchases of government securities when there are capital gains, and increase them when incurring capital losses. In other words, only if the coefficient of capital gains is negative and significant, we can support the hypothesis of portfolio rebalancing explaining net purchases of US securities. Instead, a positive and significant coefficient would point to a "momentum trading attitude" in which you buy more the more capital gains you have, and you sell the more capital losses you have. Finally, a non significant coefficient would show lack of

\footnotetext{
22 In all the estimations, we present results for a Sargan test of over-identifying restrictions that checks the overall validity of the different moment conditions and in all the cases we fail to reject the null hypothesis.

${ }^{23}$ Although we do not have problems with non stationarity (net purchases of US securities are stationary for all countries), it is worth noting that the Arellano-Bond estimator does not require time stationary while $\mathrm{T}$ is small, although instruments in levels would be weaker.

${ }^{24}$ The only condition that needs to be fulfilled is that future purchases of Treasury government bonds do not affect current exchange rates and interest rates.

${ }^{25}$ As a robustness test, we tested another de-fact exchange rate regime measure by taking a monthly variability of the exchange rates. The estimation results remain robust, however.
} 
reaction to capital gains and losses so that some other factors should be determining net purchases of government securities. From all possible factors, we include those that should be more relevant for Asian investors, mainly reserve managers, namely transaction costs, and the search for yield.

For our panel of 10 Asian countries for the period 1990 to 2004, we find evidence in favour of the portfolio rebalancing hypothesis, as shown by the very significant and negative coefficient of the capital gains variable (Table 1, column 1). As for the other two potential determinants of the purchases of US government securities (and thereby of the portfolio of reserve managers), the search for yield - measured by the Sharpe ratio -is not significant. The same is true for the transaction costs, proxied by the share of trade with the US and the degree of exchange rate flexibility. The latter should not be understood as failure of the transaction cost hypothesis altogether. In fact, they simply might not be able to explain a very volatile monthly flow variable such as the net purchases of US Treasury debt securities while they could still explain the stock of US dollar reserves in line with Heller and Knight (1978) and Dooley, Lizondo and Mathieson (1989). ${ }^{26}$

As a robustness test for the significant of the exchange rate regime in explaining the accumulation of foreign reserves in a given currency and, in particular, the purchases of US government securities, we use actual data of the volatility of the spot exchange rate of the local currency against the dollar instead of the previously employed exchange rate regime classification de facto. This is not found significant either, notwithstanding its larger volatility (Table 1, column 2).

\footnotetext{
${ }^{26}$ Though one might claim that reserve managers may adjust their preferred portfolio at much lower frequency than monthly, the transaction considerations does not reveal significant in our estimation results with annual frequency data.
} 


\begin{tabular}{|c|c|c|c|c|c|}
\hline \multicolumn{6}{|c|}{ Dependent variable - monthly net purchases of US securities (as \% of investors' wealth) } \\
\hline & $\begin{array}{c}\text { Benchmark } \\
\text { Whole } \\
\text { Sample }\end{array}$ & $\begin{array}{l}\text { Benchmark } \\
\text { Exchange } \\
\text { Variability }\end{array}$ & $\begin{array}{l}\text { Benchmark } \\
\text { Large } \\
\text { Players }\end{array}$ & $\begin{array}{l}\text { Capital } \\
\text { gains }\end{array}$ & $\begin{array}{l}\text { Capital } \\
\text { losses }\end{array}$ \\
\hline $\begin{array}{l}\text { Additional US Government Purchases } \\
\text { (of the previous period) }\end{array}$ & $\begin{array}{c}0.019 \\
(-0.035)\end{array}$ & $\begin{array}{c}0.009 \\
(0.036)\end{array}$ & $\begin{array}{c}0.013 \\
(-0.068)\end{array}$ & $\begin{array}{c}-0.185^{\star \star *} \\
(-0.041)\end{array}$ & $\begin{array}{l}-0.022 \\
(-0.048)\end{array}$ \\
\hline Capital Gains & $\begin{array}{c}-0.038^{* * *} \\
(-0.015)\end{array}$ & $\begin{array}{l}-0.033^{*} \\
(0.019)\end{array}$ & $\begin{array}{c}-0.039 \\
(-0.030)\end{array}$ & $\begin{array}{c}-0.019 \\
(-0.019)\end{array}$ & $\begin{array}{l}-0.035^{* *} \\
(-0.018)\end{array}$ \\
\hline Sharpe Ratio (of the previous period) & $\begin{array}{l}0.000 \\
(0.000)\end{array}$ & $\begin{array}{l}0.002^{* *} \\
(0.000)\end{array}$ & $\begin{array}{l}0.002^{*} \\
(-0.001)\end{array}$ & $\begin{array}{l}0.000 \\
(0.000)\end{array}$ & $\begin{array}{c}0.000 \\
(0.000)\end{array}$ \\
\hline Trade with US (of the previous period) & $\begin{array}{c}0.013 \\
(-0.037)\end{array}$ & $\begin{array}{c}0.019 \\
(0.042)\end{array}$ & $\begin{array}{c}-0.105 \\
(-0.172)\end{array}$ & $\begin{array}{c}0.015 \\
(-0.048)\end{array}$ & $\begin{array}{c}0.024 \\
(-0.041)\end{array}$ \\
\hline $\begin{array}{l}\text { Flexibility of Exchange Rate Regime } \\
\text { (of the previous period) }\end{array}$ & $\begin{array}{c}0.000 \\
(-0.001)\end{array}$ & $\begin{array}{c}0.000 \\
(0.000)\end{array}$ & $\begin{array}{c}-0.027^{* * *} \\
(-0.008)\end{array}$ & $\begin{array}{c}0.001 \\
(-0.001)\end{array}$ & $\begin{array}{l}-0.002 \\
(-0.001)\end{array}$ \\
\hline Number of Observation & 1296 & 1214 & 257 & 695 & 601 \\
\hline Chi-squared & 446.47 & 423.2 & 178.34 & 441.38 & 257.47 \\
\hline
\end{tabular}

Note: numbers in brackets are standard errors.

*** indicates that the coefficient is significant at $1 \%$.

** indicates that the coefficient is significant at $5 \%$.

* indicates that the coefficient is significant at $10 \%$.

Given their dominant role in the market, it seems important to look into the behavior of Japanese and Chinese investors, separately from other smaller Asian countries (Table 1, column 3). The portfolio rebalancing hypothesis is not confirmed but the search for yield -measured by the Sharpe ratio - becomes significant and with the expected positive sign. Concentrating on reserve managers, this result seems to indicate that profitability becomes an objective only when the level of reserves is large enough. In addition, the degree of exchange rate flexibility is also significant and with the expected sign: More exchange rate flexibility should reduce the net purchases of US government bonds and, thereby, the stock of dollar reserves, other things given.

There are some reasons to think that investors may react differently to capital gains and losses. The first and, probably most important reason is foreign exchange intervention. Asian central banks may have purchased US government securities as a way to dampen 
pressures for their currency to appreciate. This hypothesis, however, might be easier to test later, when separating capital gains into exchange rate and yield related, as we shall do later. Second, investors generally have to maintain a pre-determined level for each different investment instrument - in line with their optimal portfolio - but this might be treated as a minimum, so as to leave some space for active management on the upper side. Third, in the specific case of official authorities, unrealized losses are generally reported to calculate net profits but not unrealized gains. This might imply that unrealized losses trigger more action (for the specific hypothesis of portfolio rebalancing namely buying additional US government securities) because they have more direct consequences. In fact, we do find evidence of such asymmetric behaviour and with the expected sign: portfolio rebalancing is a significant determinant of net purchases of US securities only when there are capital losses $^{27}$ (Table 1, column 5). Capital gains, in turn, do not appear to reduce purchases of US securities (Table 1, column 4).

Given the large changes which have occurred in the period included in the above exercise-such as the Asian crisis and the huge accumulation of reserves of the last few years-we test for changes in reserve management and, particularly in our case, changes in the determinants of net purchases of US treasuries by Asian investors. To this end, we run rolling regressions of four years each. As Table 2 shows, portfolio rebalancing was a significant determinant of net purchases of US treasury securities. This result also helps explain the stability of the US dollar reserves in the years before the Asian crisis, at least as US government securities are concerned. The opposite hypothesis - of "momentum trading"- is never confirmed in the data.

Profitability considerations start becoming relevant, for the group of Asian countries as a whole, in the last few years. This finding is very much in line with the responses given by reserve managers in the Central Banking Publications survey. It also makes quite a lot of sense that reserve managers are starting to worry about profitability when reserves are well above what is needed to cover transaction needs ${ }^{28}$. Finally, transaction determinants are significant only in a couple of instances but with the right sign. First, more trade with the US

\footnotetext{
27 The negative coefficient implies net purchases since capital losses are always negative, by definition.

${ }^{28}$ Theoretical literature integrating the two-optimal reserve levels and currency decomposition of reserves (driven by the optimal portfolio theory)—hardly exists. We, thus, cannot assess the importance of the levels in the current analytical framework.
} 
contributes to larger net purchases of US government securities. Second, a more flexible exchange rate regime, de facto, reduces such purchases. 
Table 2: Rolling GMM Estimation - Whole Sample

Dependent variable - monthly net purchases of US securities (as \% of investors' wealth)

\begin{tabular}{|c|c|c|c|c|c|c|c|c|c|c|c|c|}
\hline & $90-93$ & $91-94$ & $92-95$ & $93-96$ & $94-97$ & $95-98$ & $96-99$ & $97-00$ & $98-01$ & $99-02$ & $00-03$ & $01-04$ \\
\hline \multicolumn{13}{|l|}{ Additional US Government Purchases } \\
\hline \multirow[t]{2}{*}{ (of the previous period) } & -0.111 & -0.010 & -0.007 & 0.014 & 0.022 & 0.035 & 0.042 & 0.008 & -0.015 & $0.165^{\star * *}$ & -0.098 & 0.016 \\
\hline & $(0.116)$ & $(0.086)$ & $(0.065)$ & $(0.063)$ & $(0.060)$ & $(0.060)$ & $(0.062)$ & $(0.061)$ & $(0.059)$ & $(0.057)$ & $(0.062)$ & $(0.068)$ \\
\hline \multirow[t]{2}{*}{ Capital Gains } & $-0.057^{* \star *}$ & $-0.042^{* *}$ & -0.038 & -0.034 & -0.039 & -0.040 & -0.046 & -0.027 & -0.002 & $-0.047^{*}$ & -0.023 & -0.017 \\
\hline & $(0.022)$ & $(0.019)$ & $(0.024)$ & $(0.039)$ & $(0.036)$ & $(0.037)$ & $(0.030)$ & $(0.029)$ & $(0.027)$ & $(0.026)$ & $(0.029)$ & $(0.032)$ \\
\hline \multirow[t]{2}{*}{ Sharpe Ratio (of the previous period) } & 0.000 & 0.000 & 0.000 & 0.000 & 0.000 & 0.002 & $0.002^{*}$ & $0.003^{* * *}$ & $0.004^{* * *}$ & 0.002 & $0.003^{* *}$ & 0.002 \\
\hline & $(0.000)$ & $(0.000)$ & $(0.001)$ & $(0.001)$ & $(0.002)$ & $(0.002)$ & $(0.001)$ & $(0.001)$ & $(0.001)$ & $(0.002)$ & $(0.002)$ & $(0.002)$ \\
\hline \multirow[t]{2}{*}{ Trade with US (of the previous period) } & -0.039 & -0.008 & -0.049 & 0.043 & 0.093 & 0.118 & $0.153^{*}$ & 0.069 & 0.035 & -0.000 & -0.000 & -0.025 \\
\hline & $(0.075)$ & $(0.056)$ & $(0.069)$ & $(0.086)$ & $(0.090)$ & $(0.101)$ & $(0.079)$ & $(0.064)$ & $(0.055)$ & $(0.050)$ & $(0.051)$ & $(0.060)$ \\
\hline \multirow{3}{*}{$\begin{array}{l}\text { Flexibility of Exchange Rate Regime } \\
\text { (of the previous period) }\end{array}$} & & & & & & & & & & & & \\
\hline & -0.014 & -0.013 & -0.001 & $-0.007^{*}$ & -0.001 & -0.000 & 0.000 & 0.001 & 0.000 & -0.000 & -0.001 & -0.004 \\
\hline & $(0.010)$ & $(0.009)$ & $(0.004)$ & $(0.004)$ & $(0.002)$ & 0.001 & $(0.001)$ & $(0.001)$ & $(0.001)$ & $(0.001)$ & $(0.004)$ & $(0.004)$ \\
\hline Number of Observations & 145 & 229 & 322 & 357 & 388 & 424 & 451 & 475 & 480 & 480 & 479 & 403 \\
\hline Chi-squared & 42.14 & 67.89 & 157.91 & 184.32 & 181.91 & 181.66 & 135.43 & 73.37 & 100.76 & 108.53 & 79.43 & 73.27 \\
\hline \multicolumn{13}{|l|}{ Note: numbers in brackets are standard errors. } \\
\hline \multicolumn{13}{|l|}{${ }^{* * *}$ indicates that the coefficient is significant at $1 \%$. } \\
\hline \multicolumn{13}{|l|}{ ** indicates that the coefficient is significant at $5 \%$. } \\
\hline * indicates that the coefficient is significant at $10 \%$. & & & & & & & & & & & & \\
\hline
\end{tabular}


As before, we test for the existence of asymmetries for capital gains and losses using rolling regressions. We find that the asymmetry is not as strong as that found for the full period: investors seem to react to capital gains by reducing the net purchases of US government securities during the last few years (Table A4 in the Appendix). Meanwhile, capital losses induced the rebalancing in the early 90 s (Table A5).

Another interesting question is whether investors react in the same way to exchange rate related gains/losses as well as to interest rate related ones. Table 3 shows evidence that Asian investors are more sensitive to interest rate changes in terms of rebalancing their portfolios. ${ }^{29}$ One possible explanation for this result is that investors - and in particular central banks - hedge some of the open exchange rate positions while they are fully affected by interest rate changes.

Finally, we also test for asymmetries in interest rate and exchange rate movements. A reduction in the return of US government securities (relative to euro-denominated ones), which would imply a capital loss if realized, contributes to increasing the net purchases of US government securities. This is in line with the result for capital losses as a whole and consistent with the idea that return-related capital losses are those to which investors seem to react the most. On the other hand, investors do not seem to react to losses stemming from changes in the dollar-euro exchange rate.

In fact, as far as Asian currencies move closer to the dollar than the euro and Asian central banks are known to intervene at times, we should have found that capital losses -because of a dollar depreciation against the euro and, thereby, against the domestic currency - step up purchases of US government bonds. The lack of significance of the coefficient for exchange rate losses provides some indirect evidence - given the lack of data for a direct test - against the concern that foreign exchange market intervention may be driving the net purchases of US government securities.

${ }^{29}$ Since there could be collinearity problems, we check the correlation between interest rate and exchange movements and find it to be low. 


\begin{tabular}{|c|c|c|c|c|c|}
\hline & $\begin{array}{c}\text { Benchmark } \\
\text { Whole } \\
\text { Sample }\end{array}$ & $\begin{array}{c}\text { Return-rela } \\
\text { ted gains }\end{array}$ & $\begin{array}{l}\text { Return-rela } \\
\text { ted losses }\end{array}$ & $\begin{array}{l}\text { Exchange- } \\
\text { related } \\
\text { gains }\end{array}$ & $\begin{array}{l}\text { Exchange- } \\
\text { related } \\
\text { losses }\end{array}$ \\
\hline Additional US Government Purchases_1 & $\begin{array}{c}0.019 \\
(0.035)\end{array}$ & $\begin{array}{c}-0.189^{\star * *} \\
(0.041)\end{array}$ & $\begin{array}{l}-0.022 \\
(0.048)\end{array}$ & $\begin{array}{l}-0.063 \\
(0.044)\end{array}$ & $\begin{array}{c}-0.162^{\star * \star} \\
(0.036)\end{array}$ \\
\hline Capital Gains (Interest Rate)_1 & $\begin{array}{c}-0.045^{\star * *} \\
(0.017)\end{array}$ & $\begin{array}{l}-0.032 \\
(0.021)\end{array}$ & $\begin{array}{l}-0.033^{*} \\
(0.019)\end{array}$ & $\begin{array}{l}-0.040^{*} \\
(0.025)\end{array}$ & $\begin{array}{l}-0.035^{*} \\
(0.020)\end{array}$ \\
\hline Capital Gains (Exchange Rate)_1 & $\begin{array}{c}0.079 \\
(0.137)\end{array}$ & $\begin{array}{c}0.204 \\
(0.165)\end{array}$ & $\begin{array}{l}-0.104 \\
(0.195)\end{array}$ & $\begin{array}{c}0.132 \\
(0.143)\end{array}$ & $\begin{array}{l}-0.061 \\
(0.107)\end{array}$ \\
\hline Sharpe Ratio_1 & $\begin{array}{c}0.000 \\
(0.000)\end{array}$ & $\begin{array}{c}0.000 \\
(0.000)\end{array}$ & $\begin{array}{c}0.000 \\
(0.001)\end{array}$ & $\begin{array}{c}0.001 \\
(0.001)\end{array}$ & $\begin{array}{c}0.000 \\
(0.000)\end{array}$ \\
\hline Trade with US_1 & $\begin{array}{c}0.013 \\
(0.037)\end{array}$ & $\begin{array}{c}0.015 \\
(0.048)\end{array}$ & $\begin{array}{c}0.025 \\
(0.041)\end{array}$ & $\begin{array}{l}-0.017 \\
(0.049)\end{array}$ & $\begin{array}{c}0.039 \\
(0.042)\end{array}$ \\
\hline Flexibility of Exchange Rate Regime_1 & $\begin{array}{l}-0.000 \\
(0.001)\end{array}$ & $\begin{array}{l}0.001 \\
(0.001)\end{array}$ & $\begin{array}{l}-0.002 \\
(0.001)\end{array}$ & $\begin{array}{l}-0.001 \\
(0.001)\end{array}$ & $\begin{array}{c}0.001 \\
(0.001)\end{array}$ \\
\hline Number of Observation & 1296 & 695 & 601 & 636 & 650 \\
\hline Chi-squared & 445.67 & 439.87 & 256.88 & 251.75 & 254.67 \\
\hline $\begin{array}{l}\text { Note: numbers in brackets are standard errors. } \\
\text { *** indicates that the coefficient is significant at } 1 \% \text {. } \\
{ }^{* *} \text { indicates that the coefficient is significant at } 5 \% \text {. } \\
{ }^{*} \text { indicates that the coefficient is significant at } 10 \% \text {. }\end{array}$ & & & & & \\
\hline
\end{tabular}

As for the time frame in which rebalancing occurs, we run 4-year rolling regressions as before and the results are relatively similar to those for aggregate capital gains. The only minor difference is that the response to interest rate-related capital gains/losses through portfolio rebalancing seems to be more pervasive during the period preceding the Asian crisis (see Table 4). 
Table 4: Rolling GMM Estimation - Interest Rate versus Exchange Rate Gains/Losses: Whole Sample

Dependent variable - monthly net purchases of US securities (as \% of lagged wealth)

\begin{tabular}{|c|c|c|c|c|c|c|c|c|c|c|c|c|}
\hline & $90-93$ & $91-94$ & $92-95$ & $93-96$ & $94-97$ & $95-98$ & $96-99$ & $97-00$ & $98-01$ & $99-02$ & $00-03$ & $01-04$ \\
\hline \multirow[t]{2}{*}{ Additional US Government Purchases_1 } & -0.104 & -0.006 & -0.002 & 0.014 & 0.022 & 0.035 & 0.038 & 0.007 & -0.016 & $-0.165^{* * *}$ & -0.100 & 0.011 \\
\hline & $(0.118)$ & $(0.087)$ & $(0.065)$ & $(0.063)$ & $(0.060)$ & $(0.059)$ & $(0.061)$ & $(0.061)$ & $(0.059)$ & $(0.057)$ & $(0.062)$ & $(0.068)$ \\
\hline \multirow[t]{2}{*}{ Capital Gains (Interest Rate)_1 } & $-0.056^{* *}$ & $-0.042^{*}$ & $-0.059^{* *}$ & -0.067 & $-0.084^{*}$ & $-0.099^{* *}$ & $-0.079^{* *}$ & -0.039 & -0.005 & $-0.047^{*}$ & -0.019 & -0.011 \\
\hline & $(0.028)$ & $(0.024)$ & $(0.030)$ & $(0.044)$ & $(0.043)$ & $(0.045)$ & $(0.037)$ & $(0.033)$ & $(0.030)$ & $(0.027)$ & $(0.030)$ & $(0.033)$ \\
\hline \multirow[t]{2}{*}{ Capital Gains (Exchange Rate)_1 } & 0.007 & 0.018 & 0.375 & 0.703 & $0.807^{*}$ & $0.915^{\star \star}$ & 0.471 & 0.133 & 0.025 & -0.057 & -0.088 & -0.104 \\
\hline & $(0.331)$ & $(0.292)$ & $(0.353)$ & $(0.469)$ & $(0.449)$ & $(0.426)$ & $(0.357)$ & $(0.216)$ & $(0.178)$ & $(0.149)$ & $(0.133)$ & $(0.164)$ \\
\hline \multirow[t]{2}{*}{ Sharpe Ratio_1 } & 0.000 & 0.000 & 0.000 & 0.000 & -0.000 & 0.002 & $0.002^{*}$ & $0.003^{* * *}$ & $0.004^{* * *}$ & 0.002 & $0.004^{* *}$ & 0.002 \\
\hline & $(0.000)$ & $(0.000)$ & $(0.001)$ & $(0.001)$ & $(0.002)$ & $(0.002)$ & $(0.001)$ & $(0.001)$ & $(0.001)$ & $(0.002)$ & $(0.002)$ & $(0.002)$ \\
\hline \multirow[t]{2}{*}{ Trade with US_1 } & -0.040 & -0.009 & -0.059 & 0.030 & 0.094 & 0.130 & $0.164^{\star *}$ & 0.071 & 0.036 & -0.000 & 0.001 & -0.026 \\
\hline & $(0.077)$ & $(0.057)$ & $(0.069)$ & $(0.086)$ & $(0.089)$ & $(0.010)$ & $(0.080)$ & $(0.065)$ & $(0.055)$ & $(0.050)$ & $(0.051)$ & $(0.060)$ \\
\hline \multirow[t]{2}{*}{ Flexibility of Exchange Rate Regime_1 } & -0.015 & -0.013 & -0.001 & $-0.007^{*}$ & -0.001 & -0.000 & 0.000 & 0.001 & 0.000 & -0.000 & -0.002 & -0.004 \\
\hline & $(0.010)$ & $(0.009)$ & $(0.004)$ & $(0.004)$ & $(0.002)$ & 0.001 & $(0.001)$ & $(0.001)$ & $(0.001)$ & $(0.001)$ & $(0.004)$ & $(0.004)$ \\
\hline
\end{tabular}

Constant

\begin{tabular}{|c|c|c|c|c|c|c|c|c|c|c|c|c|}
\hline Number of Observations & 145 & 229 & 322 & 357 & 388 & 424 & 451 & 475 & 480 & 480 & 479 & 403 \\
\hline Chi-squared & 41.98 & 67.77 & 156.97 & 183.86 & 180.52 & 179.54 & 134.52 & 73.57 & 100.74 & 108.76 & 80.62 & 74.78 \\
\hline \multicolumn{13}{|l|}{ Note: numbers in brackets are standard errors. } \\
\hline \multicolumn{13}{|l|}{ *** indicates that the coefficient is significant at $1 \%$. } \\
\hline \multicolumn{13}{|l|}{ ** indicates that the coefficient is significant at $5 \%$. } \\
\hline * indicates that the coefficient is significant at $10 \%$. & & & & & & & & & & & & \\
\hline
\end{tabular}


Finally, we explore whether all Asian countries in our sample behave similarly. To this end, we run 2SLS regression by country so as to take care of potential endogeneity. We use the lagged dependent variable as an instrument. We find confirmation of portfolio rebalancing for Indonesian, Malaysian, and Chinese investors. On the contrary, momentum trading is confirmed for Philippine investors. For Japan and Philippines, the search for yield is found significant and with the expected sign: the higher the expected risk-adjusted yield, the more net purchases of US government securities there will be. Finally, in Korea and Indonesia, an increase in the share of trade with the US steps up the next purchases of US government securities. Interestingly, the opposite sign is found significant for Japan. Finally, a more flexible exchange rate regime does reduce China's purchases of US government securities. 


\begin{tabular}{|c|c|c|c|c|c|c|c|c|c|c|}
\hline & Hong Kong & Indonesia & India & Japan & Korea & Malaysia & Philippines & China & Singapore & Thailand \\
\hline \multirow[t]{2}{*}{ Capital Gains_1 } & 0.056 & $-0.100^{\star * *}$ & -0.008 & -0.012 & 0.023 & $-0.152^{* * *}$ & $0.088^{* * *}$ & $-0.185^{\star}$ & -0.074 & -0.017 \\
\hline & $(0.072)$ & $(0.027)$ & $(0.025)$ & $(0.026)$ & $(0.039)$ & $(0.038)$ & $(0.033)$ & $(0.097)$ & $(0.058)$ & $(0.029)$ \\
\hline \multirow[t]{2}{*}{ Sharpe Ratio_1 } & -0.000 & 0.001 & 0.000 & $0.003^{* * *}$ & 0.001 & 0.000 & $0.001^{* *}$ & -0.001 & -0.004 & 0.000 \\
\hline & $(0.002)$ & $(0.001)$ & $(0.000)$ & $(0.001)$ & $(0.001)$ & $(0.001)$ & $(0.001)$ & $(0.004)$ & $(0.002)$ & $(0.001)$ \\
\hline \multirow[t]{2}{*}{ Trade with US_1 } & -0.010 & $0.250^{* *}$ & -0.009 & $-0.283^{*}$ & $0.271^{*}$ & 0.044 & -0.040 & -0.033 & 0.072 & -0.001 \\
\hline & $(0.340)$ & $(0.114)$ & $(0.026)$ & $(0.169)$ & $(0.156)$ & $(0.070)$ & $(0.055)$ & $(0.397)$ & $(0.224)$ & $(0.080)$ \\
\hline \multirow[t]{2}{*}{ Flexibility of Exchange Rate Regime_1 } & --- & 0.002 & 0.000 & --- & -0.000 & -0.001 & -0.001 & $-0.036^{\star * *}$ & -0.005 & 0.001 \\
\hline & --- & $(0.002)$ & $(0.002)$ & --- & $(0.003)$ & $(0.001)$ & $(0.001)$ & $(0.010)$ & $(0.005)$ & $(0.002)$ \\
\hline Number of Observations & 87 & 143 & 139 & 147 & 147 & 147 & 148 & 112 & 88 & 148 \\
\hline R-squared & 0.008 & 0.125 & 0.005 & 0.091 & 0.034 & 0.123 & 0.094 & 0.125 & 0.053 & 0.008 \\
\hline \multicolumn{11}{|l|}{ Note: numbers in brackets are standard errors. } \\
\hline \multicolumn{11}{|l|}{ *** indicates that the coefficient is significant at $1 \%$. } \\
\hline \multicolumn{11}{|l|}{ ** indicates that the coefficient is significant at $5 \%$. } \\
\hline * indicates that the coefficient is significant at $10 \%$. & & & & & & & & & & \\
\hline
\end{tabular}




\section{Conclusions}

This paper explores whether Asian investors - and in particular official authorities rebalance their portfolios as a consequence of capital gains or losses. Portfolio rebalancing would imply that investors increase their net purchases of US government securities after incurring capital losses so as to maintain their desired portfolio. Instead, they should sell securities after obtaining capital gains to achieve the same objective.

We choose the market of US government debt securities since we need to concentrate on one single investment instrument (in one single currency) to readily calculate capital gains and losses. In addition, this is the most widely used instrument by central banks to hold their reserves in dollar. Finally, we focus on Asian countries because they are very important investors in the market of US government securities and because their activity is concentrated in the hands of central banks. Their purchases of US government securities can shed some light of their reserve management strategies.

We find evidence of portfolio rebalancing for a group of 10 Asian countries for the period from 1990 until end 2004 although it was more significant in the years before the Asian crisis. In the last few years, profitability considerations are more and more relevant for Asian investors. In addition, capital losses tend to contribute more to additional net purchases of US securities than capital gains do to reducing such purchases. This could be due to the way investment strategies are designed but also to the fact that official investors generally treat unrealized losses as actual losses but not unrealized gains. Finally, we find that Asian investors are more sensitive to interest rate movements than to exchange rate movements when rebalancing their portfolio. This probably reflects more hedging of foreign exchange risk than of interest rate risk.

The evidence found in favor of portfolio rebalancing by Asian investors points to their stabilizing role in that market. In fact, portfolio rebalancing reduces the likelihood of one-directional movements in their purchases of US Treasury securities, which- given their size in the market and the size of the US fiscal deficit- may have positive systemic implications, in terms of reduction of global financial market volatility. This statement is especially true for the years prior to the Asian crisis. In most recent years, the chase for return has become more relevant in explaining net purchases of US treasury securities. 
This might have brought some more volatility to the share of US dollar reserves, other factors given. 


\section{REFERENCES}

Arellano, M. and S. Bond. 1991. Some tests of specification for panel data: Monte Carlo evidence and an application to employment equations. The Review of Economic Studies 58: 277-297.

Bank of Japan, 2005. "Basic Guidelines for the Management of External Assets Held by Bank of Japan", available at http://www.boj.or.jp/en/type/law/hyoryo01.htm.

Ben-Bassat, Avraham, 1980. "The Optimal Composition of Foreign Exchange Reserves," Journal of International Economics: 10; 285-295.

Bohn, Henning and Linda Tesar, 1996. "US Equity Investment in Foreign Markets: Portfolio Rebalancing or Return Chasing?", American Economic Review, Vol. 86, No 2, Paper and Proceedings of the Hundredth and Eighth Annual Meeting of the American Economic Association.

Carver, Nick, and Robert Pringle, 2004. "Survey of Central Bank Risk Managers" in New Horizons in Central Bank Risk Management", R. Pringle and N. Carver eds. Central Banking Publications Ltd

Claessens, Stijn, and Jerome Kreuser, 2004. "A framework for strategic foreign reserves risk management”, in Risk Management for Central Bank Foreign Reserves. Bernadell et al. eds. European Central Bank.

Dooley, Michael, Saul Lizondo and Donald Mathieson, 1989. "The Currency Composition of Foreign Exchange Reserves”, IMF Staff Papers, Vol.36 No 2.

Fisher, Stephen J. and Min C. Lie, 2004. "Asset allocation for central banks: optimally combining liquidity, duration, currency and non-government risk" in Risk Management for Central Bank Foreign Reserves. Bernadell et al. eds. European Central Bank.

Hau, Harald and Helene Rey, 2004. "Can Portfolio Rebalancing Explain the Dynamics of Equity Returns, Equity Flows and Exchange Rates?”, mimeo

McCauley, Robert and Ben Fung, 2003. "Choosing Instruments in Managing Foreign Exchange Reserves”, BIS Quarterly Bulletin, March 2003.

Reinhart, Carmen M. and Kenneth S. Rogoff, 2004. "The Modern History of Exchange Rate Arrangements: A Reinterpretation," Quarterly Journal of Economics, vol. CXIX Issue 1: $1-48$.

Truman Edwin and Anne Wong, 2006. "The Case for an International Diversification Standard".

Wooldrigde, Philip, 2006. "The Changing Composition of Official Reserves”, BIS Quarterly Bulletin, September 2006. 


\section{APPENDIX}

Table A1: Data source

\begin{tabular}{|l|l|l|l|}
\hline Variable & Original Series & Definition / Units & Source \\
\hline $\begin{array}{l}\text { Net purchases } \\
\text { of US } \\
\text { Treasury } \\
\text { securities }\end{array}$ & $\begin{array}{l}\text { Purchases of US } \\
\text { Treasury securities - } \\
\text { Sales of US Treasury } \\
\text { securities }\end{array}$ & www.treas.gov/tic \\
\hline $\begin{array}{l}\text { Foreign } \\
\text { exchange } \\
\text { reserves }\end{array}$ & $\begin{array}{l}\text { Foreign Exchange } \\
\text { Reserves }\end{array}$ & $\begin{array}{l}\text { (in millions of US dollars) } \\
\text { Curo/US\$ Exchange } \\
\text { rate and three year } \\
\text { benchmark yield on } \\
\text { US and German } \\
\text { bonds }\end{array}$ & IMF-IFS \\
\hline $\begin{array}{l}\text { Erade share } \\
\text { with US }\end{array}$ & $\begin{array}{l}\text { Share of trade with } \\
\text { US }\end{array}$ & $\begin{array}{l}\text { (Imports + exports to US } \\
\text { of Country i) / (Total } \\
\text { Imports + exports of } \\
\text { Country i) }\end{array}$ & IMF-IFS \\
\hline $\begin{array}{l}\text { Exchange rate } \\
\text { regime } \\
\text { classification }\end{array}$ & $\begin{array}{l}\text { Exchange Rate } \\
\text { Classification from } \\
\text { Reinhart and Rogoff } \\
\text { (2004) }\end{array}$ & $\begin{array}{l}\text { Categorical, from 2 } \\
\text { (pre-announced peg or } \\
\text { currency board } \\
\text { arrangement) to 14 } \\
\text { (Freely Falling and } \\
\text { Hyperfloat) }\end{array}$ & $\begin{array}{l}\text { Reinhart and Rogoff } \\
\text { (2004) } \\
\text { http://www.puaf.umd. } \\
\text { edu/faculty/papers/re } \\
\text { inhart/links.htm }\end{array}$ \\
\hline $\begin{array}{l}\text { Euro/US\$ Exchange } \\
\text { rate and three year } \\
\text { benchmark yield on } \\
\text { US and German } \\
\text { government bonds }\end{array}$ & $\begin{array}{l}\text { Equation (4) } \\
\text { Standard deviation of the } \\
\text { preceding 2 years (t-1 to } \\
\text { t-24) is used to divide the } \\
\text { time t return. }\end{array}$ & Bloomberg \\
\hline
\end{tabular}

Table A2: Statistical summary

\begin{tabular}{lcccc}
\hline \multicolumn{1}{c}{ Variable } & Mean & Std. Dev. & Min & Max \\
\hline Net Purchases of US Treasury securities / & & & & \\
Foreign Exchange Reserves in the previous & & & & \\
period & 0.00 & 0.02 & -0.20 & 0.19 \\
$\quad \begin{array}{l}\text { Trade share with US } \\
\text { Exchange Rate regime classification }\end{array}$ & 0.23 & 0.08 & 0.07 & 0.50 \\
$\quad \begin{array}{l}\text { Capital Gains: } \\
\quad \text { Exchange Rate growth (Euro/US) }\end{array}$ & 7.90 & 3.94 & 2 & 14 \\
$\quad$ Relative Interest rate gain (US vs German & 0.00 & 0.03 & -0.12 & 0.07 \\
bonds) & 0.00 & 0.28 & -0.90 & 0.86 \\
Sharpe Ratio & -2.34 & 10.75 & -47.11 & 10.68 \\
\hline
\end{tabular}

Note: Average values of 10 countries. 
Table A3: Granger causality Wald tests based on 2 variables VAR

\begin{tabular}{|c|c|c|}
\hline \multicolumn{3}{|c|}{ Ho: Coefficients of HP_W are zero. } \\
\hline & chi2 & Prob > chi2 \\
\hline Hong Kong & 0.13 & 0.94 \\
\hline Indonesia & 2.75 & 0.25 \\
\hline India & 20.81 & 0.00 \\
\hline Japan & 0.35 & 0.84 \\
\hline Korea & 8.35 & 0.02 \\
\hline Malaysia & 5.54 & 0.06 \\
\hline Philippines & 5.06 & 0.08 \\
\hline PRC & 12.44 & 0.00 \\
\hline Singapore & 7.13 & 0.03 \\
\hline Thailand & 3.37 & 0.19 \\
\hline
\end{tabular}


Table A4: Rolling GMM Estimation - Sample of Positive Gains

Dependent variable - monthly net purchases of US securities (as \% of lagged investors' wealth)

\begin{tabular}{|c|c|c|c|c|c|c|c|c|c|c|c|c|}
\hline & $90-93$ & $91-94$ & $92-95$ & 93-96 & 94-97 & $95-98$ & $96-99$ & $97-00$ & $98-01$ & $99-02$ & 00-03 & 01-04 \\
\hline \multirow{3}{*}{$\begin{array}{l}\text { Additional US } \\
\text { Government Purchases } \\
\text { (of the previous } \\
\text { period) }\end{array}$} & & & & & & & & & & & & \\
\hline & $-0.613^{* * *}$ & $-0.528^{* * *}$ & $-0.260^{* * *}$ & $-0.191^{\star * *}$ & -0.095 & -0.080 & -0.066 & -0.124 & $-0.162^{* \star}$ & $-0.214^{* * *}$ & $-0.218^{* * *}$ & $-0.249^{* * *}$ \\
\hline & $(0.139)$ & $(0.079)$ & $(0.073)$ & $(0.075)$ & $(0.078)$ & $(0.076)$ & $(0.092)$ & $(0.077)$ & $(0.070)$ & $(0.064$ & $(0.070)$ & $(0.087)$ \\
\hline \multirow[t]{2}{*}{ Capital Gains } & -0.015 & -0.008 & 0.021 & 0.051 & -0.051 & -0.049 & -0.063 & $-0.071^{* *}$ & -0.012 & $-0.074^{\star *}$ & -0.035 & -0.042 \\
\hline & $(0.029)$ & $(0.022)$ & $(0.032)$ & $(0.048)$ & $(0.047)$ & $(0.052)$ & $(0.039)$ & $(0.036)$ & $(0.035)$ & $(0.031$ & $(0.030)$ & $(0.036)$ \\
\hline \multirow[t]{2}{*}{$\begin{array}{l}\text { Sharpe Ratio (of the } \\
\text { previous period) }\end{array}$} & 0.000 & 0.000 & -0.000 & 0.000 & -0.000 & 0.002 & $0.003^{* *}$ & $0.003^{* * *}$ & $0.003^{* * *}$ & 0.002 & 0.003 & 0.003 \\
\hline & $(0.000)$ & $(0.000)$ & $(0.000)$ & $(0.002)$ & $(0.003)$ & $(0.002)$ & $(0.001)$ & $(0.001)$ & $(0.001)$ & $(0.002)$ & $(0.002)$ & $(0.002)$ \\
\hline \multirow[t]{2}{*}{$\begin{array}{l}\text { Trade with US (of the } \\
\text { previous period) }\end{array}$} & -0.034 & -0.000 & -0.025 & 0.013 & 0.076 & 0.045 & 0.106 & 0.021 & 0.016 & 0.031 & 0.014 & -0.012 \\
\hline & $(0.100)$ & $(0.075)$ & $(0.108)$ & $(0.120)$ & $(0.127)$ & $(0.128)$ & $(0.109)$ & $(0.082)$ & $(0.062)$ & $(0.058)$ & $(0.054)$ & $(0.061)$ \\
\hline \multicolumn{13}{|c|}{ Flexibility of Exchange } \\
\hline \multirow[t]{2}{*}{$\begin{array}{l}\text { Rate Regime (of the } \\
\text { previous period) }\end{array}$} & $-0.020^{*}$ & $-0.021^{* *}$ & -0.017 & $-0.015^{\star \star}$ & 0.000 & 0.001 & 0.000 & $0.002^{* *}$ & $0.002^{*}$ & 0.000 & -0.001 & -0.003 \\
\hline & $(0.009)$ & $(0.009)$ & $(0.014)$ & $(0.006)$ & $(0.002)$ & $(0.002)$ & $(0.001)$ & $(0.001)$ & $(0.001)$ & $(0.001)$ & $(0.003)$ & $(0.003)$ \\
\hline $\begin{array}{l}\text { Number of } \\
\text { Observations }\end{array}$ & 61 & 91 & 139 & 156 & 205 & 235 & 228 & 270 & 291 & 311 & 320 & 238 \\
\hline Chi-squared & 58.76 & 80.04 & 170.1 & 162.6 & 146.9 & 152.7 & 61.51 & 41.21 & 77.47 & 75.43 & 54.51 & 49.22 \\
\hline $\begin{array}{l}\text { Note: numbers in brackets ar } \\
{ }^{* * *} \text { indicates that the coefficie } \\
{ }^{* *} \text { indicates that the coefficier } \\
{ }^{*} \text { indicates that the coefficien }\end{array}$ & $\begin{array}{l}\text { re standard err } \\
\text { ent is significan } \\
\text { nt is significant } \\
\text { th is significant }\end{array}$ & $\begin{array}{l}\text { rors. } \\
\text { th at } 1 \% \text {. } \\
\text { t at } 5 \% \text {. } \\
\text { at } 10 \% \text {. }\end{array}$ & & & & & & & & & & \\
\hline
\end{tabular}


Table A5: Rolling GMM Estimation - Sample of Negative Gains

Dependent variable - monthly net purchases of US securities (as \% of lagged investors' wealth)

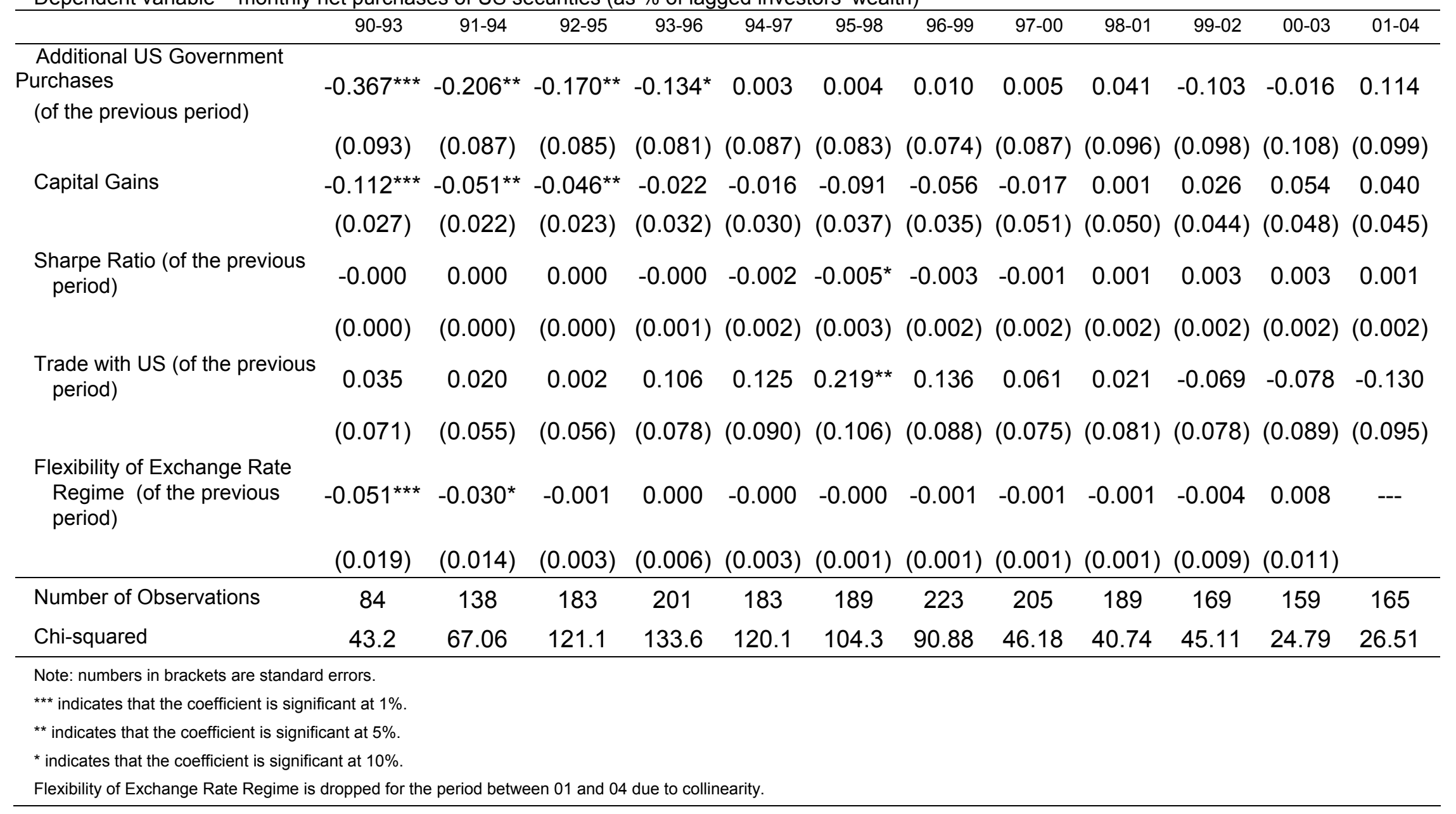

